\title{
Sclerocorneal limbal stem cell autograft transplantation in dogs
}

\author{
[Transplante autógeno de células tronco do limbo esclerocorneal em cães]
}

\author{
A.T.J. Brunelli ${ }^{1}$, F.A.M. Vicente ${ }^{1}$, F. Chahud ${ }^{2}$, A.P. Oriá $^{1}$, A.A. Bolzan ${ }^{1}$, C.F. Campos ${ }^{1}$, \\ F.A. Doria Neto ${ }^{1}$, J.L. Laus ${ }^{3 *}$ \\ ${ }^{1}$ Aluno de pós-graduação - FCAV-UNESP - Jaboticabal, SP \\ ${ }^{2}$ Aluno de pós-graduação - USP - Ribeirão Preto, SP \\ ${ }^{3}$ Faculdade de Ciências Agrárias e Veterinárias - UNESP \\ Via de Acesso Prof. Paulo Donato Castellane, s/n \\ 14884-900 - Jaboticabal, SP
}

\begin{abstract}
The effects of sclerocorneal limbal stem cell autograft transplantation in dogs with corneal wounds were studied. Eighteen dogs were divided in two groups (GI and GII). The animals of GI ( $\mathrm{n}=12$ ) underwent limbal transplantation 30 days after the destruction of limbal stem cells. The dogs of GII $(n=6)$ only underwent destruction of stem cells (control group). Light microscopy examination of the right eye was performed on days 3, 7, 14, 30, 60, and 120 after limbal transplantation (GI), and on days 33, 37, 44, 60, 90, and 150 after limbal destruction (GII). Results showed a complete destruction of limbal stem cells with loss of corneal transparency. Limbal transplantation prevented conjunctivalization in grafted area. Corneal vascularization and a $360^{\circ}$ corneal conjunctivalization were noted in the control dogs (GII). Corneal transparency was restored from day $60^{\text {th }}$ after surgery. Histological examination did not distinguish the transition between the graft and the normal corneal epithelium at anytime. Goblet cells were found in control animals (GII) on 33, 37, 60, and 150 days, whereas a single grafted dog (GI) presented a few goblet cells on day $60^{\text {th }}$ post-transplantation. Limbal autograft transplantation was effective in restoring corneal clarity with no development of ocular complications.
\end{abstract}

Keywords: dog, stem cells, limbus, autograft transplantation

\section{RESUMO}

Avaliaram-se os efeitos do transplante de células tronco autógenas do limbo esclerocórneo de cães, sobre lesões córneo-limbais. Empregaram-se 18 cães, distribuídos em dois grupos, GI e GII. Nos animais do GI $(n=12)$, foram realizados transplantes de limbo, após 30 dias da destruição das células troncolímbicas. Nos do GII (n=6), realizou-se apenas a destruição do limbo (controle). Aos 3, 7, 15, 30, 60 e 120 dias do transplante de limbo (GI) e aos 33, 37, 45, 60, 90 e 150 dias da destruição do limbo (GII), os olhos foram coletados por enucleação subconjuntival, para estudos em microscopia de luz. A destruição do limbo resultou em completa excisão das células tronco, com perda da transparência corneal. $O$ transplante do limbo evitou a conjuntivalização na área em que foi realizado. Os animais do grupocontrole manifestaram conjuntivalização em $360^{\circ}$ e vascularização corneal. Na anatomopatologia, em nenhum dos periodos foi possivel distinguir o enxerto do epitélio corneal normal. As células caliciformes foram observadas nos animais do GII, nos periodos 33, 37, 60, 150 dias. No GI, apenas um cão manifestou células caliciformes de forma discreta, aos 60 dias do transplante. O transplante autógeno foi eficiente em possibilitar a melhoria da transparência córnea, sem intercorrências oculares.

Palavras-chave: cão, células tronco, limbo, transplante autógeno

Recebido em 18 de novembro de 2005

Aceito em 13 de agosto de 2007

*Corresponding author (autor para correspondência)

E-mail: jllaus@fcav.unesp.br 


\section{INTRODUCTION}

Stem cells are responsible for tissue replacement and regeneration (Akped and Foster, 1999). They are essential to maintain the integrity of corneal surface, by promoting its renewal in healthy states and reepithelialization in wound healing processes (Swift et al., 1996; Haamann et al., 1998; Dua and Azuara-Blanco, 1999).

Stem cells are believed to be located in the limbal basal epithelium (Chung et al., 1992). The exact location of corneal stem cells was proved by using monoclonal antibodies (Schermer et al., 1986; Chung et al., 1992), and by stimulating corneal and limbal cells with a tumor-promoting agent (Cotsarelis et al., 1989). Also, impression cytology and histology were used for this purpose (Puangsricharern and Tseng, 1995).

Limbal deficiency or loss of stem cells is characterized by a reduction of proliferative capacity, resulting in abnormal corneal surface (Akped and Foster, 1999). In such occasions, there is growth of the conjunctival epithelium onto the corneal surface (conjunctivalization), as well as chronic inflammation, superficial vascularization, calcification, ulceration, melting and perforation of the cornea (Swift et al., 1996; Tseng and Tsubota, 1997; Dua and AzuaraBlanco, 1999; Dua and Azuara-Blanco, 2000). When corneal surface is covered by conjunctival epithelium, goblet cells can be seen in this specialized part of the fibrous tunic (Dua, 1998; Schwab, 1999).

The symptoms of limbal deficiency may include photophobia, decreased vision, tearing, blepharospasm, and redness (Dua and AzuaraBlanco, 1999). Untreated limbal and corneal injuries may result in persistent epithelial defects, conjunctivalization of the cornea, destructive lesions of the basal membrane, and perforation of the cornea (Chan and Foster, 1999).

Surgical procedures are required to treat severe lesions and restore the integrity of ocular surface (Coster et al., 1995). Either total or partial autograft transplantation is recommended in patients with limbal stem cell deficiency. When autograft transplantation is not possible, limbal allograft can be alternatively used (Coster et al., 1995; Dua and Azuara-Blanco, 1999).
Taking into account that partial or total destruction of the sclerocorneal limbal stem cells results in very significant corneal alterations, this study aimed at investigating the proposal of an experimental model of limbal destruction, as well as its consequences and the effects of limbal autograft transplantation in dogs.

\section{MATERIAL AND METHODS}

Eighteen adult healthy mixed-breed dogs of either sex were used. The bioethical handling of animals followed the rules given by the Association for Research in Vison and Ophthalmology according to the Nüremberg code (Goldim, 1995) and the Comissão de Ética na Experimentação Animal da Faculdade de Ciências Agrárias e Veterinárias - UNESP Jaboticabal, SP.

Food and water were withheld for an 8-hour period prior to the operative procedures. Animals were pre-medicated with levomepromazine ${ }^{1}$, $1 \mathrm{mg} / \mathrm{kg} \mathrm{IV}$, followed by anesthetic induction with sodium tiopental ${ }^{2} \quad 12.5 \mathrm{mg} / \mathrm{kg}$ IV. A halogenated anesthetic agent ${ }^{3}$ diluted in oxygen was delivered via a closed anesthetic circuit to maintain anesthesia in the third plane of the third stage (Guedel, 1952).

Only one surgeon performed all the procedures. The destruction of stem cells was performed in only one eye (right eye). For such, a sterile cotton tip wet with n-heptanol solution ${ }^{4}$ was applied to the eye in a circular fashion for 120 seconds, beginning centrally and extending to the bulbar conjunctiva to cause total deepithelialization. The area was immediately rinsed with sterile saline solution ${ }^{5}$ for two minutes to remove the excess of $n$-heptanol. Since the procedure alone is not able to completely remove stem cells, a $360^{\circ}$ lamellar keratectomy was employed as an ancillary method (Tsai et al., 1990).

Keratectomy was started after routine preparation, protection, and antiseptic treatment of the operative field with $10 \%$ buffered

\footnotetext{
${ }^{1}$ Neozine ${ }^{\circledR}$ - Laboratório Rhodia

${ }^{2}$ Thiopentax ${ }^{\circledR}$ - Laboratório Cristália

${ }^{3}$ Fluotane ${ }^{\circledR}$ - Laboratório Astrazeneca

${ }^{4} \mathrm{~N}$-heptanol solution - Merck-Achuchardt

${ }^{5}$ Sterile $0.9 \%$ saline solution - JP Indústria Farmacêutica S.A.
} 
polyvinylpyrrolidone - iodine solution (PVPI) diluted in saline solution ${ }^{5}(1 / 50)$. Under six-time magnification provided by the operating microscope ${ }^{7}$, the limbal zone was excised in a $360^{\circ}$ lamellar pattern, removing approximately $2 \mathrm{~mm}$ of the cornea and $3 \mathrm{~mm}$ of the conjunctiva. To allow this procedure, a \#66 Beaver blade ${ }^{8}$ and Barraquer scissors were used. The ocular surface was systematically irrigated with sterile $0.9 \%$ saline solution ${ }^{5}$ during the procedure. After surgery, fluorescein test ${ }^{9}$ was performed to delimit the injured area.

After the surgical maneuvers, the animals wore Elizabethan collars. All dogs were prophylactically given topical tobramicine ${ }^{10}$ and nonsteroidal anti-inflammatory flurbiprofen ${ }^{11}$, both at regular non-coincident 6-hour intervals for 14 consecutive days. To reduce ciliary spasm, $1 \%$ atropine eyedrops ${ }^{12}$ was instilled at 12 -hour intervals for three days, followed by use every 24 hours for further three days. It was also instituted analgesic and anti-inflammatory therapy with oral meloxicam ${ }^{13} 0.1 \mathrm{mg} / \mathrm{kg}$ of body weight, daily for five days.

One month after limbal destruction, the animals were divided into two groups. GI was composed of 12 dogs that were submitted to limbal autograft transplantation, and GII was composed of six dogs used as control.

After preparation and protection of the operating field, limbal stem cells were collected from the fellow eye (left eye). Under a 6-time magnification provided by an operating microscope ${ }^{7}$, superficial lamellar dissection of the peripheral cornea was carried out to remove two 3-mm-conjunctival strips involving the limbal circumference of 11-13 and 17-19 o'clock (Fig. 1A). Grafts were stored at room temperature in a sterile recipient containing autologous serum for the least required time until transplantation was performed.

\footnotetext{
${ }^{6}$ Marcodine Tópico ${ }^{8}$ - Innovatec - Divisão Cristália

${ }^{7}$ Microscope MC-M900-D.F. Vasconcellos S.A.

${ }^{8} \# 66$ Beaver blade ${ }^{\circledR}$ Alcon Surgical

${ }^{9}$ Ophthalmos ${ }^{\circledR}$ - Ophthalmos Ind. Com. Prod. Farm. Ltda.

${ }^{10}$ Tobrex ${ }^{\circledR}$ - Alcon Laboratórios do Brasil

${ }^{11}$ Ocufen ${ }^{\circledR}$ - Laboratório Allergan-Frumtost

${ }^{12}$ Atropine $1 \% ®$ - Laboratório Allergan-Lok

${ }^{13}$ Maxican ${ }^{\circledR}$ Laboratório Ouro Fino
}

The graft was transplanted to the recipient eye shortly after its excision. After preparation and protection of the surgical area, the limbal graft was transferred to the recipient bed and sutured at the 11-to-13-o'clock and 17-to-19-o'clock positions, extending $2 \mathrm{~mm}$ into the cornea and $3 \mathrm{~mm}$ beyond the conjunctiva (Tan et al., 1996) (Fig. 1B and 1C). The grafts were secured to the bulbar conjunctiva and cornea with seven nonpenetrating interrupted 9-0 monofilament nylon sutures $^{14}$. A distance of $1 \mathrm{~mm}$ was left between sutures (Fig. 1D).

Every dog wore an Elizabethan collar after surgery. Topical tobramicine ${ }^{10}$ and nonsteroidal anti-inflammatory flurbiprofen ${ }^{11}$ were used four times a day for the first seven days, followed by topical trobramicine and dexametasone eyedrops and ointments ${ }^{15}$ four times daily for the next seven days. Atropine eyedrops ${ }^{12}$ was used at 12 hour intervals for three days and every day for further three days. Also, dogs were given Buprenorfin $^{16}, 3 \mu \mathrm{g} / \mathrm{kg} \mathrm{IM}$, for three consecutives days and meloxican ${ }^{13}, 0.1 \mathrm{mg} / \mathrm{kg}$ orally every 24 hours for five days.

Each dog was daily examined by the same person for any signs of blepharospasm, ocular discharge, conjunctival injection, chemosis, corneal neovascularization, corneal opacity and pigmentation, and conjunctivalization. The results were analyzed under subjective quantitative criteria. The dogs were daily examined at the slit lamp ${ }^{17}$, applanation tonometry $^{18}$, Schirmer's tear test ${ }^{19}$, and fluorescein test ${ }^{9}$. Fisher's exact test was used to analyze clinical signs at a significance level of $5 \%(\mathrm{P} \leq 0.05)$.

Histological examination was performed on days $3,7,14,30,60$, and 120 after limbal transplantation in GI dogs, and on days 33,37 , 44, 60, 90, and 150 after limbal destruction in animals of GII. Each evaluation included two dogs of GI and one dog of GII.

\footnotetext{
${ }^{14}$ Mononylon 9-0 - Ethicon S.A.

${ }^{15}$ Tobramax ${ }^{\circledR}$ colírio e pomada - Alcon Laboratórios do Brasil

${ }^{16}$ Temgesi ${ }^{\circledR}$ - Schering Ploug

${ }^{17}$ Portable stit-lamp SL-14 - Kowa

${ }^{18}$ Tono-pen XL, Mentor ${ }^{\circledR}$

${ }^{19}$ Schimer's Tear test - Ophtalmos Ind. Com. Prod. Farma. Ltda.
} 


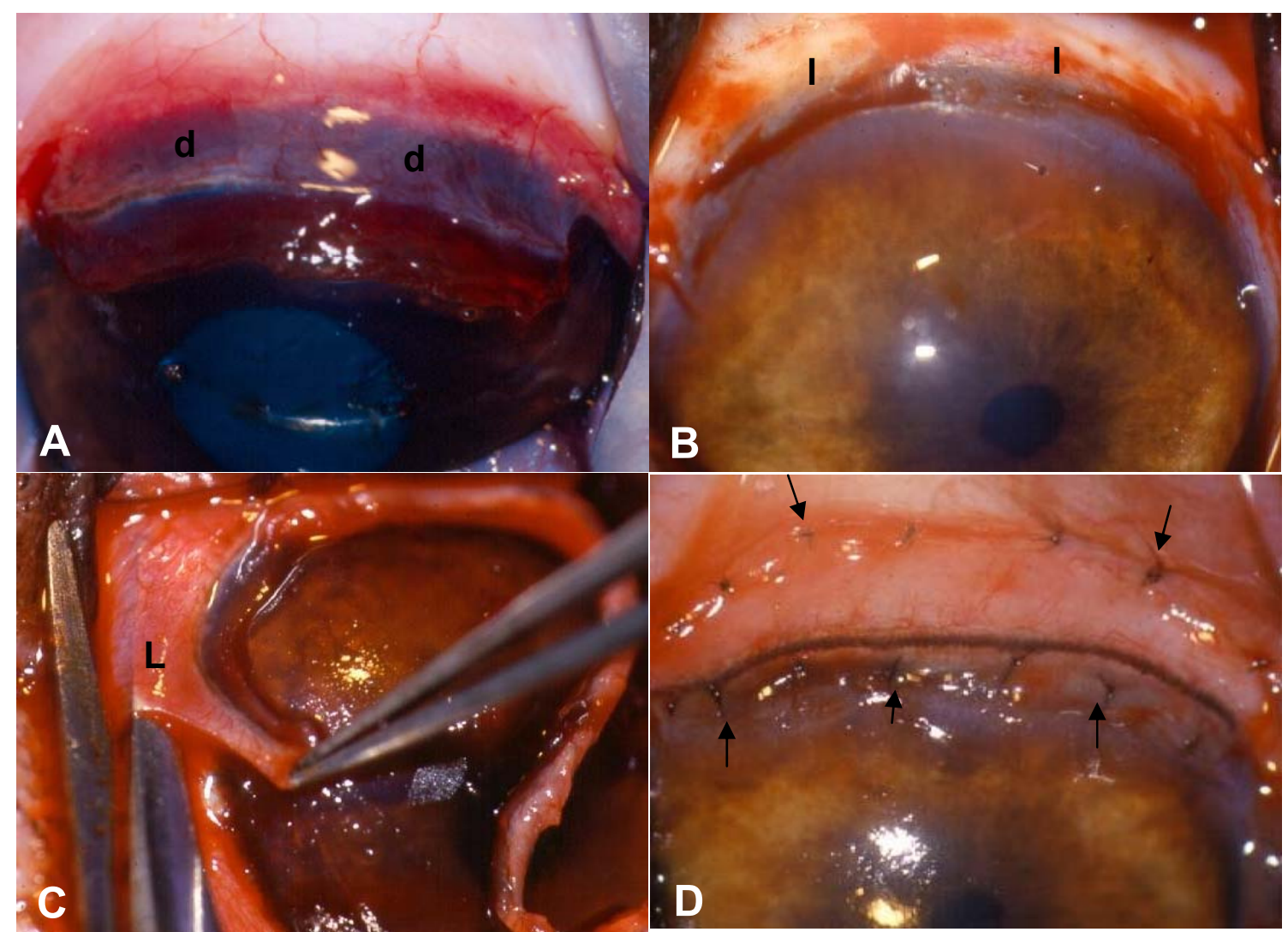

Figure 1. Photographs images of dog eyes. A: Collecting sclerocorneal limbus (d) from the fellow eye (left eye), extending $2 \mathrm{~mm}$ into the cornea and $3 \mathrm{~mm}$ beyond the conjunctiva. $\mathbf{B}$ and $\mathbf{C}$ : Preparation of the recipient bed (right eye) (L) for graft fixation. D: Limbal fixation with non-penetrating interrupted 9-0 monofilament nylon sutures (arrows) at the 11-to-13-o'clock position.

\section{RESULTS}

No alterations were observed in intraocular pressure and Schirmer's tear test after limbal ablation. Corneal vascularization reached up to $2 \mathrm{~mm}$ beyond the limbus in $83.3 \%$ of the animals and $4 \mathrm{~mm}$ beyond the limbus in $16.7 \%$ of the dogs seven days after limbal destruction. Corneal vascularization was seen in every animal on day $14^{\text {th }}$. Neovessels reached $2 \mathrm{~mm}, 4 \mathrm{~mm}$, and $6 \mathrm{~mm}$ beyond the limbus in $33.3 \%, 33.3 \%$, and $33.3 \%$ of the dogs, respectively.

Thirty days after injury, vascularization was still seen in all animals. Most of them (72.2\%) had 6$\mathrm{mm}$ neovessels extending from the limbus into central cornea. In $27.8 \%$ of the dogs, however, vessels were not $4 \mathrm{~mm}$ beyond the limbus.

Corneal granulation tissue developed seven days after ablation, being mild in $22.2 \%$, moderate in
$11.1 \%$, and severe in $22.2 \%$ of the dogs. No granulation tissue was seen in $44.4 \%$ of the animals. On day $14^{\text {th }}$, granulation was absent in $33.3 \%$ of the animals, mild in $16.7 \%$, moderate in $5.6 \%$, and severe in $50 \%$. On day $30^{\text {th }}$, most dogs did not show any granulation tissue $(61.1 \%)$, whereas in $16.7 \%, 5.6 \%$, and $16.7 \%$ of the animals, it was observed in mild, moderate, and severe grades, respectively.

Severe keratitis was observed in $11.1 \%$ of the cases on day $14^{\text {th }}$. In such animals, the most representative findings were mucopurulent ocular discharge, deep corneal neovessels, severe corneal edema, granulation, and thickening of the cornea. Such signs tended to regression on day $30^{\text {th }}$. Table 1 shows the results regarding ocular discharge, blepharospasm, chemosis, conjunctival injection, pigmentation, conjunctivalization, and fluorescein test. 
Table 1. Progression of clinical picture on days 3, 7, 14, 30, 60, and 120 after limbal destruction in dogs

\begin{tabular}{l|llll}
\hline \multirow{2}{*}{ Parameter } & \multicolumn{4}{c}{ Days after limbal destruction } \\
\cline { 2 - 5 } & 3 & 7 & 14 & 30 \\
\hline Ocular discharge & + & + & + & - \\
Blepharospasm & $-/+$ & - & - & - \\
Chemosis & $+/++$ & + & - & - \\
Conjunctival injection & +++ & $++/+++$ & $+/++$ & + \\
Corneal opacity & + & $+/+++$ & $+/+++$ & + \\
Corneal pigmentation & - & - & - & + \\
Conjunctivalization & - & - & + & ++ \\
Fluorescein test & + & + & - & - \\
\hline
\end{tabular}

Assessed in accordance with subjective quantitative criteria: - (absence of signs), + (mild manifestation of signs), ++ (moderate signs), and +++ (severe signs).

No systemic or ocular complications were observed in animals of GI. There was no dehiscence, infection, limbal graft rejection, or any significant manifestations besides those usually observed in similar procedures. None of the animals developed either ulcerative keratitis or granulation. Also, the results of intraocular pressure and Schirmer's tear test were within the normal range in all times.

Three days after limbal transplantation, $25 \%$ of GI dogs had developed corneal vascularization up to $2 \mathrm{~mm}$ beyond the limbus. In $58.3 \%$ of the animals, neovessels reached up to $6 \mathrm{~mm}$ beyond the limbus, whereas in the remaining dogs $(25 \%)$, it was only observed vessels on central corneal. Regarding the animals of control group (GII), corneal neovascularization up to $2 \mathrm{~mm}$ and $6 \mathrm{~mm}$ beyond the limbus was seen in $16.7 \%$ and $67.7 \%$ of the dogs, respectively. In the remaining $16.7 \%$, neovessels were only observed on central corneal.

After seven days, neovessels reached up to $2 \mathrm{~mm}$ in $40 \%$ of GI dogs and $20 \%$ of GII dogs. In $50 \%$ of GI animals and $60 \%$ of GII animals, the vessels reached up to $6 \mathrm{~mm}$ beyond the limbus. Central corneal neovascularization was seen in $10 \%$ of GI dogs and $20 \%$ of GII.

Fourteen days after limbal transplantation, 37.5\% of GI dogs and $25 \%$ of GII dogs had neovessels reaching up to $2 \mathrm{~mm}$ beyond the limbus, whereas in $50 \%$ of GI and GII dogs, neovascularization reached up to $6 \mathrm{~mm}$. In the remaining $12.5 \%$ of GI dogs and $25 \%$ of GII dogs, neovascularization was located on central cornea.

On day $30^{\text {th }}$, no vascularization was seen in $16.7 \%$ of GI dogs. Neovessels reaching up to
$2 \mathrm{~mm}$ and $6 \mathrm{~mm}$ beyond the limbus was found in $50 \%$ and $16.66 \%$ of the animals, respectively. Vessels were equally distributed in dogs of GII ( $2 \mathrm{~mm}, 6 \mathrm{~mm}$, and on central cornea).

On day $60^{\text {th }}$, neovascularization reached $2 \mathrm{~mm}$ and $6 \mathrm{~mm}$ beyond the limbus in $50 \%$ and $25 \%$ of GI dogs, respectively. In the remaining $25 \%$, vessels were located on central cornea. In GII, $50 \%$ of the dogs had neovessels reaching up to $2 \mathrm{~mm}$ beyond the limbus, whereas in $50 \%$ they reached $6 \mathrm{~mm}$ beyond the limbus.

On day $120^{\text {th }}$, neovessels reached $2 \mathrm{~mm}$ beyond the limbus in $50 \%$ of GI dogs, whereas the remaining $50 \%$ had neovessels on central corneal. In every animal of control group the vessels reached $2 \mathrm{~mm}$ beyond the limbus.

Animals of group GI did not exhibit conjunctivalization at the transplantation site. In the control group without transplantation, however, a $360^{\circ}$ corneal conjunctivalization was observed.

Results of ocular discharge, blepharospasm, chemosis, conjunctival injection, pigmentation, conjunctivalization, and fluorescein test are shown in Tables 2 and 3. The clinical evolution is presented in Fig. 2 (A, B, C, D, E, F, G, H).

No alterations in intraocular pressure and Schirmer's tear test occured. Seven days after surgical procedure, all dogs had developed corneal neovascularization. On day $14^{\text {th }}$, neovessels were limited to the wound area in most dogs $(87.5 \%)$. In contrast, neovascularization was not seen in the remaining $12.5 \%$. Thirty days after injury, vascularization was present in only $33.3 \%$ of the animals, 
whereas in $66.7 \%$ it was absent. At the end of two months, $50 \%$ of the dogs had superficial corneal vessels reaching $2 \mathrm{~mm}$ beyond the limbus. On day $120^{\text {th }}$, however, no corneal vessels were seen anymore. Results of ocular discharge, blepharospasm, chemosis, conjunctival injection, pigmentation, conjunctivalization, and fluorescein test are shown in Table 4.

Table 2. Progression of clinical picture on 3, 7, 14, 30, 60, and 120 days after limbal autograft transplantation (GI) in dogs

\begin{tabular}{l|llllll}
\hline \multirow{2}{*}{ Parameter } & \multicolumn{7}{c}{ Days after limbal autograft transplantation } \\
\cline { 2 - 7 } & 3 & 7 & 14 & 30 & 60 & 120 \\
\hline Ocular discharge & + & + & $-/+$ & - & - & - \\
Blepharospasm & $-/+$ & - & - & - & - & - \\
Chemosis & $-/++$ & $-/+$ & $-/+$ & - & - & - \\
Conjunctival injection & +++ & ++ & ++ & + & $-/+$ & $-/+$ \\
Corneal opacity & $+/++$ & $+/++$ & + & + & + & + \\
Corneal pigmentation & + & $-/+$ & $-/+$ & + & - & $-/+$ \\
Fluorescein test & - & - & - & - & - & - \\
\hline
\end{tabular}

Assessed in accordance with subjective quantitative criteria: - (absence of signs), + (mild manifestation of signs), ++ (moderate signs), and +++ (severe signs).

Table 3. Progression of clinical picture on days 33, 37, 44, 60, 90 and 150 after limbal destruction (GII) in dogs

\begin{tabular}{l|llllll}
\hline \multirow{2}{*}{ Parameter } & \multicolumn{7}{c}{ Days after limbal destruction } \\
\cline { 2 - 7 } & 33 & 37 & 44 & 60 & 90 & 150 \\
\hline Ocular discharge & - & - & - & - & - & - \\
Blepharospasm & - & - & - & - & - & - \\
Chemosis & - & - & - & - & - & - \\
Conjunctival injection & + & + & + & + & + & - \\
Corneal opacity & $+/++$ & $+/++$ & + & + & $-/+$ & + \\
Corneal pigmentation & + & + & $+/++$ & $+/++/+++$ & $++/+++$ & +++ \\
Fluorescein test & - & - & - & - & - & - \\
\hline
\end{tabular}

Assessed in accordance with subjective quantitative criteria: - (absence of signs), + (mild manifestation of signs),++ (moderate signs), and +++ (severe signs).

Table 4. Progression of clinical evolution of donor eye on days 3, 7, 14, 30, 60 and 120 after limbal autograft transplantation in dogs

\begin{tabular}{l|llllll}
\hline \multirow{2}{*}{ Parameter } & \multicolumn{5}{c}{ Days after limbal autograft transplantation } \\
\cline { 2 - 6 } Ocular discharge & 3 & 7 & 14 & 30 & 60 & 120 \\
Blepharospasm & + & - & - & - & - & - \\
Chemosis & - & - & - & - & - & - \\
Conjunctival injection & $-/+$ & - & - & - & - & - \\
Corneal opacity & ++ & + & $-/+$ & - & - & - \\
Corneal pigmentation & + & + & + & - & - & - \\
Conjunctivalization & - & - & - & - & - & - \\
Corneal granulation & - & - & $-/+$ & $-/+$ & - & - \\
Fluorescein test & - & $-/+$ & - & - & - & - \\
\hline Assed & + & - & - & - & - & - \\
\hline
\end{tabular}

Assessed in accordance with subjective quantitative criteria: - (absence of signs), + (mild manifestation of signs), ++ (moderate signs), and +++ (severe signs). 

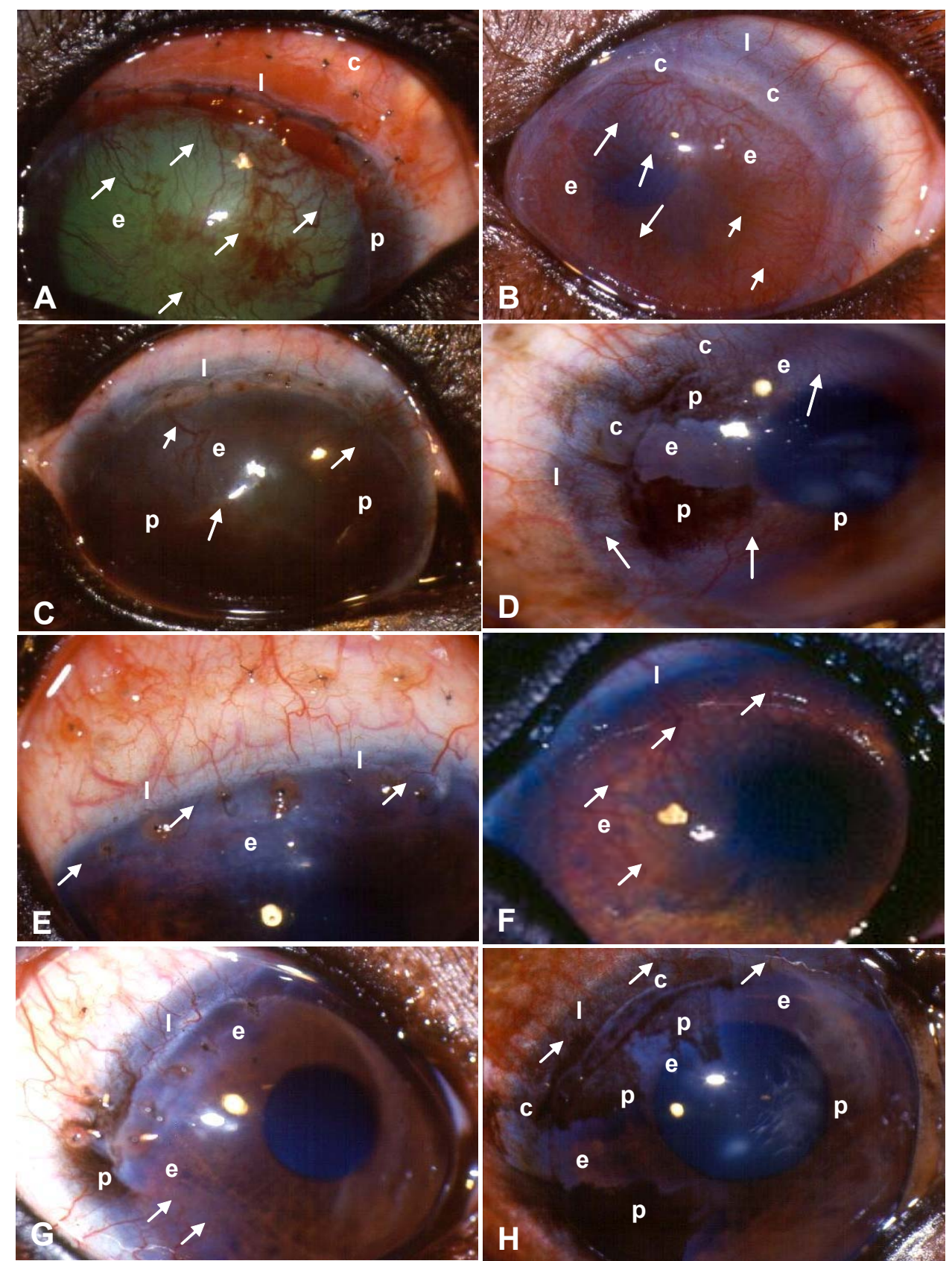

Figure 2. Photographs images of eyes of dogs after sclerocorneal limbal autograft transplantation (GI) and of control group dogs (GII). A: 3rd day after surgery (GI): note conjunctival injection (c), edema (e), graft (l), pigmentation (p), and vascularization on central cornea (arrows). B: $33^{\text {th }}$ day after limbal injury (GII): observe the site of sclerocorneal limbal destruction (1), conjunctivalization (c), corneal edema (e), and vascularization (arrows). C: $14^{\text {th }}$ day postsurgery (GI): note edema (e), transplantation site (l), pigmentation (p), and vascularization over central cornea (arrows). D: $44^{\text {th }}$ day after limbal destruction (GII): note the site of sclerocorneal limbal destruction (l), conjunctivalization (c), corneal edema (e), vascularization (arrows), and pigmentation (p). E: $30^{\text {th }}$ day after transplantation (GI): note edema (e), absence of distinction between the graft and either corneal or conjunctival epithelia (1), vascularization reaching $2 \mathrm{~mm}$ beyond the limbus (arrows). F: $60^{\text {th }}$ day after limbal injury (GII): note the site of limbal destruction (1), edema (e), and vascularization (arrows). G: $120^{\text {th }}$ day post-transplantation (GI): note edema (e), pigmentation (p), transplantation area (l), and vascularization (arrows). $\mathbf{H}$ : $150^{\text {th }}$ day after limbal destruction (GII): note the site of limbal destruction (1), conjunctivalization (c), corneal edema (e), vascularization reaching $2 \mathrm{~mm}$ beyond the limbus (arrows), and pigmentation (p). 
Results of data analysis by Fisher's test are shown in Table 5. Statistical analysis was not carried out on day $120^{\text {th }}$ due to the reduced number of animals in either group (two dogs in GI and one dog in GII).

In GI, the transition between limbal autograft and normal corneal epithelium at anytime could not be distinguished. It was therefore defined by the localization of sutures.
In GI, the epithelium healed within three days of transplantation, although focal irregularities due to its thickness and to epithelial cells hyperplasia were present. Goblet cells were not observed in this area. Thirty-three days after limbal destruction (GII), corneal thickness decreased in both peripheral and central cornea, and a reduced number of goblet cells was seen in corneal epithelium.

Table 5. Lowest significant (P) occurrence of blepharospasm, ocular discharge, conjunctival injection, chemosis, edema, orneal vascularization and pigmentation, and conjunctivalization on days $3,7,14,30$, and 60 in groups after scherocorneal autograft limbal transplantation and in control dogs

\begin{tabular}{l|lllll}
\hline \multirow{2}{*}{ Parameter } & \multicolumn{5}{|c}{ Days } \\
\cline { 2 - 6 } & 3 & 7 & 14 & 30 & 60 \\
\hline Ocular discharge & 0,0070 & 0,0170 & 1,0000 & $1,0000-$ & 1,0000 \\
Blepharospasm & 0,6765 & 1,0000 & 1,0000 & 1,0000 & 1,0000 \\
Chemosis & 0,6765 & 1,0000 & 1,0000 & 1,0000 & 1,0000 \\
Conjunctival injection & 1,0000 & 0,7502 & 0,6566 & 0,4286 & 1,0000 \\
Corneal opacity & 0,5362 & 1,0000 & 1,0000 & 1,0000 & 0,6000 \\
Corneal vascularization & 1,0000 & 0,7502 & 0,6566 & 0,4286 & 1,0000 \\
Corneal pigmentation & 0,5200 & 0,6154 & 0,2889 & 0,5238 & 0,7333 \\
Conjunctivalization & 0,0005 & 0,0033 & 0,0020 & 0,0111 & 0,0667 \\
\hline
\end{tabular}

Seven days after transplantation (GI) and 37 days after limbal ablation (GII), epithelial hyperplasia was noted in central cornea of GI animals, whereas in GII, an intact epithelium with normal thickness was observed. Goblet cells were not seen in GI corneas. In contrast, a moderate number of goblet cells were found in the peripheral cornea of GII dogs.

Although focal peripheral corneal irregularities were seen on day $14^{\text {th }}$ after transplantation, a healed epithelium was noted in every animal of GI. Also, no goblet cells were found in any dog except in one, in which they were mildly distributed along the corneal periphery. Fortyfour days after limbal destruction (GII), a normally thickened epithelium was found, and no corneal goblet cells were noted.

Thirty days after transplantation, the dogs of GI showed thickened areas in both peripheral and central cornea, and goblet cells were absent in the corneal epithelium. Sixty days after injury, corneal periphery exhibited a reduced epithelial layer in the control group without transplantation (GII). Also, goblet cells were moderately present in peripheral and central corneal epithelia.
Later (on $60^{\text {th }}$ and $120^{\text {th }}$ days), epithelial hyperplasia was observed in every dog of either group. In only one animal of GI, goblet cells were found in the peripheral corneal epithelium. The histologic examination is presented in Fig. 3 (A, B, C, D, E, and F).

\section{DISCUSSION}

Experimental limbal destruction is performed to induce corneal alterations similar to accidental lesions and to further study effective therapeutic alternatives. Both chemical debridement (nheptanol, iodine, sodium hydroxide solution) and mechanical debridement (corneal scarification, superficial keratectomy) have been described in rabbits, guinea pigs, and primates (Hirst et al., 1981; Kruse et al., 1990).

Chemical debridement with n-heptanol aims at removing corneal epithelium without damaging the basal layer (Hirst et al., 1981; Kruse et al., 1990). Kenyo and Tseng (1989), however, showed that n-heptanol alone did not remove the entire limbal epithelium. To extinguish stem cells completely, limbal epithelium might be removed thoroughly to avoid the mobilization of surrounding transient amplifying cells and stem cells (Chen and Tseng, 1990). 


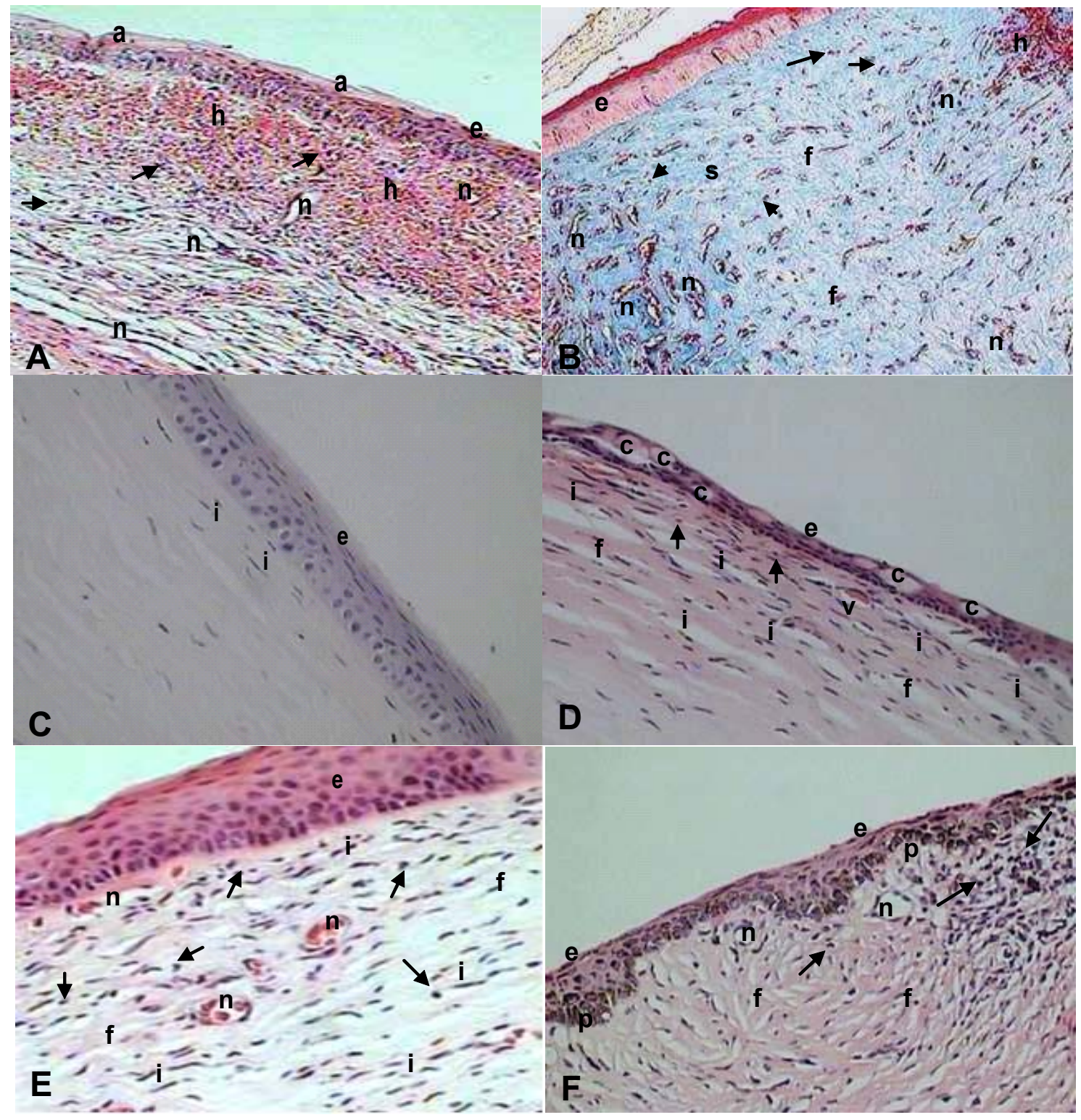

Figure 3. Photomicrographs of peripheral corneas of dogs. A: Third day after transplantation (GI): note area of keratinization (a), hemorrhage (h), inflammatory cells (arrows), irregular epithelium (e), and vascularization (n) (200X, HE). B: 33rd day post-limbal destruction (GII): observe the hemorrhagic area (h), corneal epithelium (e), corneal stroma (s), tissue fibrosis (f), inflammatory infiltrate (arrows), and vascularization (n) (200X, Masson's trichrome). C: 30th day post-limbal transplantation (GI): note fibroblasts (i), and an irregular corneal epithelium (e) (200X, HE). D: 60th day after limbal ablation (GII): note epithelial thinning (e), goblet cells (c), fibroblasts (i), fibrosis (f), inflammatory infiltrate (arrows), and vessels (n) (400X, HE). E: 120th day following transplantation (GI): note fibroblasts (i), fibrosis (f), epithelial hyperplasia (e), inflammatory infiltrate (arrows), and vessels (n) (400X, HE). F: 150th day postlimbal destruction (GII): note fibrosis (f), inflammatory infiltrate (arrows), an irregular corneal epithelium (e), vessels (n), and pigmentation (p) (400X, HE). 
In a pilot study of our laboratory, n-heptanol debridement for 60 seconds followed by lamellar keratectomy failed to cause severe corneal alterations, resulting in mild edema and vascularization, and rapid epithelial healing. Therefore, it was observed that n-heptanol shold be applied to the eye for 120 seconds, which resulted in a thorough removal of stem cells.

Although Huang and Tseng (1988) and Kenyon and Tseng (1989) reported that in the absence of limbal epithelium corneal wound healing becomes less efficient, characterized by recurrent erosions. This finding was observed in this study. Corneal healing was achieved within 20 days after limbal destruction, without recurrent erosions over 150 days post-ablation.

Conjunctival epithelial ingrowth onto the cornea is dependent on the variable extent of the ocular lesion and removal of stem cells (Chen and Tseng, 1990; Tsai et al., 1990). Most times conjunctivalization is accompanied by corneal vascularization (TSAI et al., 1990). In this study, conjunctivalization and vascularization started within seven days after limbal destruction, and progressed in every animal, over 30 days after wounding.

After limbal autograft transplantation, Tsai et al. (1990) found corneal vascularization in four of five rabbits, on $120^{\text {th }}$ day of evaluation. In the current report, vessels extending $2 \mathrm{~mm}$ beyond the limbus, were observed in $50 \%$ of the dogs, whereas in the remaining, they were noted in central cornea. Fargerholm and Lisha (1999) suggested that the regression of vessels might indicate an interaction between corneal epithelium and stroma that is not observed when conjunctivalization is present.

Intense pigmentation was seen in the animals of group GII 150 days after limbal destruction. In the group of limbal transplantation, mild-toabsent pigmentation was noted. When present, it was located next to the limbal area not covered by the grafts.

Limbal stem cells are recognized to play a vital role in corneal epithelial cell renewal. Therefore, ocular surface damages may develop in their absence (Tseng and Tsubota, 1997). In this study, exuberant granulation was especially seen, on day $14^{\text {th }}$ after limbal ablation, with regression by day 30. Tsai et al. (1990) observed granulation at the end of the fourth month after limbal injury, in rabbits, however, in the dogs of this study, in which granulation lasted for a maximum of 46 days after limbal destruction, that event could not be documented.

Conjunctival goblet cells were found on corneal epithelium. The presence of goblet cells substantiates that conjunctivalization occurred following limbal destruction. Fagerholm and Lisha (1999) showed that in the human being eye, goblet cells are found on corneal epithelium after chemical burns. In the current study, goblet cells were documented 33 days after limbal ablation, particularly in control group animals, and in a single grafted dog. Fagerholm and Lisha (1999) further reported that the success of limbal transplantation might be confirmed by the absence of goblet cells in the corneal epithelium.

After transplantation, corneal and limbal epithelial healing was achieved between three and 21 days. This finding is in agreement with studies by Kenyo and Tseng (1989) and Tan et al. (1996). In human beings, Fagerholm and Lisha (1999) reported epithelial proliferation at two weeks post-transplantation. In dogs, however, healed corneal epithelium was noted three days post-transplantation, although hyperplasia was also present.

As reported by Dua and Azuara-Blanco (2000), no complications occurred in donor eyes. Corneal edema, vascularization, and conjunctivalization started regressing 60 days after surgery and complete regression was observed up to 60 days later. Although Morgan and Murray (1996) reported corneal microperforations in donor eyes of human beings such complication was not noticied in this research.

\section{CONCLUSIONS}

The dog model of total limbal destruction is feasible and reliable in producing severe ocular surface wounds, resulting in loss of corneal clarity. Limbal autograft transplantation was effective in restoring the corneal transparency with no ocular complications. The absence of complications in the donor eyes of dogs is an evidence of the advantages and efficacy of limbal autograft transplantation, in managing 
stem cell deficiency, after mechanical trauma or chemical injury.

\section{ACKNOWLEDGMENT}

The authors thank to Dr. Gener Tadeu Pereira for performing the statistical analysis. The Programa de Internacionalização da Pesquisa da UNESP. Research supported by Conselho Nacional de Desenvolvimento Científico e Tecnológico CNPq.

\section{REFERENCES}

AKPED, E.K.; FOSTER, C.S. Limbal stem cells transplantation. Int. Ophthalmol. Clin., v.39, p.71-81, 1999.

CHAN, R.Y.; FOSTER, C.S. A step-wise pproach to ocular surface rehabilitation in patients with ocular inflammatory disease. Int. Ophthalmol. Clin., v.39, p.83-107, 1999.

CHEN, J.J.Y.; TSENG, S.C.G. Corneal epithelial wound healing in partial limbal deficiency. Invest. Ophthalmol. Visual Sci., v.31, p.1301-1314, 1990.

CHUNG, E.H.; BUKUSOGLU, G.; ZIESKE, J.D. Localization of corneal epithelium stem cells in the developing rat. Invest. Ophthalmol. Visual Sci., v.33, p.21992206, 1992.

COSTER, D.J.; AGGARWAL, R.K.O.; WILLIAMS, K.A. Surgical management of ocular surface disorders using conjunctival and stem cells allografts. Br. J. Ophthalmol., v.79, p.977-982, 1995.

COTSARELIS, G.; CHEN, S.Z.; LAVKER, R.M. Existence of slow-cycling limbal epithelial basal cells that can be preferentially stimulated to proliferate: implications on epithelial stem cells. Cell, v.57, p.201-209, 1989.

DUA, H.S. The conjuntival in corneal epithelial wound healing. Br. J. Ophthalmol., v.82, p.1407-1411, 1998.

DUA, H.S.; AZUARA-BLANCO, A. Allo-limbal transplantation in patients with limbal stem cell deficiency. Br. J. Ophthalmol., v.83, p.414-419, 1999.

DUA, H.S.; AZUARA-BLANCO, A. Limbal stem cells of corneal epithelium Surv. Ophthalmol., v.44, p.415-425, 2000.

FAGERHOLM, P.; LISHA, G. Corneal stem cells grafting after chemical injury. Acta Ophthalmol. Scand., v.77, p.165$169,1999$.
GOLDIM, J. R. Pesquisa em saúde e direitos dos animais. Porto Alegre: HCPA, 1995. 28p.

GUEDEL, A. E. (Ed). Inhalation anesthesia. 2.ed. New York: Macmillian, 1952.

HAAMANN, P.; JENSEM, O.M.; SCHIMIDT, P. Limbal autograft transplantation. Acta Ophthalmol. Scand., v.76, p.117-118, 1998 .

HIRST, L.W.; KENYON, K.R.; FOGLE, J.A. et al. Comparative studies of corneal surface injury in the mankey and rabbit. Arch. Ophthalmol., v.99, p.1066-1073, 1981.

HUANG, A.J.W.; TSENG, S.C.G. Corneal epithelial wound healing in the absence of limbal epithelium. ARVO Abstracts. Invest. Ophthalmol. Visual Sci., v.29, suppl., p.190, 1988.

KENYON, K.R.; TSENG, S.C.G. Limbal autograft transplantation for ocular surface disorders. Ophthalmology, v.96, p.709-723, 1989.

KRUSE, F.E.; CHEN, J.J.Y.; TSAI, R.J.F. et al. Conjunctival transdifferentiation is due to the incomplete removal of limbal basal epithelium. Invest. Ophthalmol. Visual Sci., v.36, p.1903-1913, 1990.

MORGAN, S.; MURRAY, A. Limbal auto-transplantation in the acute ang chronic phases of severe chemical injuries. Eye, v.10, p.349-354, 1996.

PUANGSRICHARERN, V.; TSENG, S. C. G. Citology evidence of corneal diseases with limbal stem cells deficiency. Ophthalmology, v.102, p.1476-1485, 1995.

SCHERMER, A.; GALVIN, S.; SUN, T.T. Differentiationrelated expression of a major $64 \mathrm{~K}$ corneal keratin in vivo and in culture suggests limbal location of corneal epithelial stem cells. J. Cell Biol., v.103, p.49-62, 1986.

SCHWAB, I.R. Cultured corneal epithelia for ocular surface disease. Transact. Am. Soc., v.97, p.891-939, 1999.

SWIFT, G.J.; AGGARWAL, R.K.; DAVIS, G.J. et al. Survival of rabbit limbal stem cell allografts. Transplatation, v.62, p.568-574, 1996.

TAN, D.T.; FICKER, L.A.; BUCKLEY, R.J. Limbal transplantation. Ophthalmology, v.103, p.29-36, 1996.

TSAI, R.J.; SUN, T.T.; TSENG, S.C.G. Comparison of limbal and conjunctival autograft transplantion in corneal surface reconstruction in rabbits. Ophthalmology, v.97, p.446-455, 1990.

TSENG, S.C.G.; TSUBOTA, K. Important concepts for treating ocular surface and tear disorders. Am. J. Ophthalmol., v.124, p.825-835, 1997. 